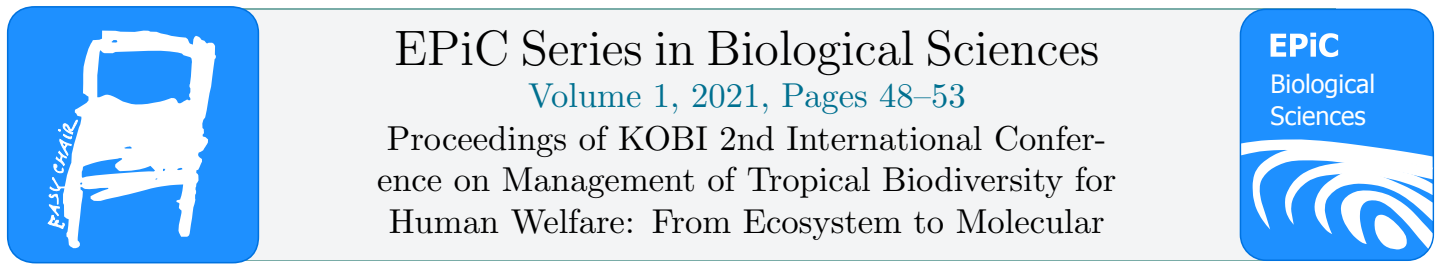

\title{
Molecular Sex Determination of Masked Lovebird (Agapornis personata) by Polymerase Chain Reaction Method
}

\author{
Shafira Inggrid El Islami ${ }^{1}$, Medania Purwaningrum ${ }^{1}$ and Aris Haryanto ${ }^{1 *}$ \\ Universitas Gadjah Mada, Yogyakarta, Indonesia. \\ arisharyanto@ugm.ac.id
}

\begin{abstract}
Sex determination in monomorphic birds such as masked lovebird (Agapornis personata) based on physical appearance is difficult to conduct. It becomes a problem in the breeding program. Some rapid methods for sex determination have been developed, one of which is molecular sexing based on the amplification of Chromodomain Helicase DNA-binding (CHD) gene by polymerase chain reaction (PCR) method using specific primers. This method is a solution with rapid and accurate results. The aim of this study was to molecular sex determine of masked lovebird by PCR amplification. The feather samples were collected from ten masked lovebirds. DNA was isolated from the chalamus, part of the lovebird feather and it was used as a DNA template for PCR amplification. The PCR products then were electrophoresed in agarose gel and they were visualized by SYBRSafe staining on a UV transilluminator. It showed that a single DNA fragment in size of 400 bp generated for male masked lovebirds and double DNA fragments in size of $350 \mathrm{bp}$ and $400 \mathrm{bp}$ generated for female masked lovebirds.
\end{abstract}

\section{Introduction}

Lovebird is a type of bird that has been maintained because it has several advantages, namely physical characteristics, color feathers, and charming behavior. The main interest of Lovebird is because of its attractive coat color (Handono et al., 2013). Anatomically, Lovebird has a compact body, a shorttailed with blunt-ended and a sharp beak. Wild Lovebird has a dominant green color with variation color in the upper body depending on the species of Lovebird (Nurfianto and Mulyanto, 2017).

Lovebird consists of nine species which are divided into two groups, namely dimorphic and monomorphic groups. A dimorphic group is a lovebird group in which male and female birds can be distinguished physically, for example, the Agapornis cana, Agapornis taranta, and Agapornis pullaria. While the monomorphic group is a group of lovebirds which is physically the same between males and females, so it is difficult to distinguish. Species of monomorphic lovebird are Agapornis swinderniana, 
Agapornis nigrigenis, Agapornis fischeri, Agapornis personata, Agapornis lilianae, and Agapornis roseicollis (Yudiantoro and Maloedyn, 2011).

Agapornis personata is known as masked lovebird because of its black-haired face with white eye circles, like wearing a mask. Species of masked lovebird found and spread in Zambia, Burundi, Malawi, and Central Tanzania (Handono et al., 2013). This lovebird has a characteristic with a dominant green color and about $14.5 \mathrm{~cm}$ body length. The color of the head to the neck is black and the neck has a circular yellow, whereas the chest is bright yellow which is brighter than the color of the neck. The bird's beak is bright red and the feet are grey-black. Male and female lovebirds have the same external appearance and belong to monomorphic species. The mutation of masked lovebird color generated color gradation of blue and light blue, while the color of the head and neck remains brownish-black (Benjamin and Yasyifa, 2017).

Various methods for sex determination of birds have been developed, such as karyotype, hormone analysis, laparoscopy, and laparotomy, but these methods have various disadvantages such as timeconsuming and costly, invasive and difficult to apply in the field or can only be carried out at certain times (Nugroho dan Zein, 2015). Molecular sexing is a molecular technique for the sex determination of birds rapidly and accurately. This technique was developed based on the marker of specific chromosome gene by the considering variations between heterogametic sex chromosome (female birds have $\mathrm{Z}$ and $\mathrm{W}$ chromosomes) and homogametic sex chromosome (male birds have double $\mathrm{Z}$ chromosomes) (Morinha et al., 2012).

Methods for molecular sex-determining based on differences in the size of the intron Chromodomain Helicase DNA-binding (CHD) gene on $\mathrm{Z}$ and $\mathrm{W}$ chromosomes in birds have been developed. The CHD gene is the first gene proposed as a valid marker to sex differentiate in various species of birds. CHD gene has a less difference in the size and sequence of nucleotides between several CHD-1Z and CHD-1W introns (Dubiec and Neubauer, 2006). This work used ten lovebirds from species of Agapornis personata or in Indonesian terms called as masked lovebird. The aim of this study was to molecular sex determine of masked lovebird by PCR amplification method of Chromodomain Helicase DNA-binding gene using specific DNA primer from feather samples.

\section{Materials and Methods}

This research was performed in the Department of Biochemistry, Faculty of Veterinary Medicine, Universitas Gadjah Mada, Yogyakarta from October 2018 to January 2019. The research samples were feathers from ten masked lovebirds (Agapornis personata) individually from bird owners and are labeled as sample number AP-1 to AP-10. DNA was isolated from samples based on the Gsync DNA Extraction Kit (Geneaid) protocol, but the incubation time was extended to overnight aimed at making DNA well extracted so that the DNA bands produced when exposed to UV light became clearer.

Products of DNA isolation were used as DNA templates for amplification using the PCR method by targeting to the CHD gene on the sex chromosome using P2, NP, and MP specific primers. The nucleotide sequence of primers is presented in Table 1. A mixture of $25 \mu \mathrm{L}$ of PCR reagents for DNA template for each reaction mix consists of myTaq ${ }^{\mathrm{TM}}$ DNA Polymerase, forward primer [10 pmol], reverse primer $[10 \mathrm{pmol}]$, and DNA template. The mixture was put into the thermocycler with controlled temperature and duration of the PCR reaction. Cyle of PCR began by pre-denaturation step of $94^{\circ} \mathrm{C}$ for 2 minutes, denaturation of $94^{\circ} \mathrm{C}$ for 20 seconds, annealing $46^{\circ} \mathrm{C}$ for 30 seconds, the extension of $72^{\circ} \mathrm{C}$ for 40 seconds, and finally at the end by post-extension at $72^{\circ} \mathrm{C}$ for 10 minutes. The denaturation, annealing, and extension stages were repeated in 40 PCR cycles.

The product of DNA isolation and PCR amplification were separated by agarose gel electrophoresis. Ten of PCR products were mixed with loading dye and compared with 100 bp ladder DNA markers. Electrophoresis was done in a $2.5 \%$ agarose gel at a voltage of 100 volts and an electric current of 75 
amperes for 45 minutes. DNA bands were observed using UV Transilluminator with a wavelength of $280 \mathrm{~nm}$ in the darkroom.

\begin{tabular}{ccc}
\hline Primer & Base arrangement & PCR products (bp) \\
\hline NP-F & 5'-GAGAAACTGTGCAAAACAG-3' & 350 \\
P2-R & 5'-TCTGCATCGCTAAATCCTTT-3' & 400 \\
MP-R & 5'-AGTCACTATCAGATCCGGAA-3, & 350 \\
\hline & Table 1: Primary base arrangements and PCR products (Ito et al., 2003).
\end{tabular}

\section{Results and Discussion}

Molecular sexing is a method for sex-determining which has developed since the year 1990 (Morinha et al., 2012). In general, birds including masked lovebird have sex chromosomes that are different from mammals. Mammals have XY heterozygous sex chromosomes in males and homozygous $\mathrm{XX}$ in females. In birds including lovebird, it is the opposite, where $\mathrm{ZW}$ heterozygous chromosome sex is in female lovebird while homozygous ZZ in male lovebird (Grant, 2001).

In this study used feather samples collected from ten masked lovebirds (Agapornis personata) which sent by lovebird owners. The extracted feather samples are then given a sample code AP-1 to AP-10. DNA was isolated from ten samples of masked lovebird (Agapornis personata) feathers. Source of DNA from lovebird feathers obtained from the base of the feather called chalamus which still contains many epithelial cells and keratin which can inhibit the process of DNA extraction so that it becomes more difficult to extract (Hickman et al., 1984). DNA extraction using an extraction kit produces better DNA quality but increases the costs. For optimization, in this study, the DNA extraction process using an extraction kit was performed by extending the incubation time to overnight, so that it can obtain a good DNA template. The results of the DNA template electrophoresis extraction results are presented in Figure 1.

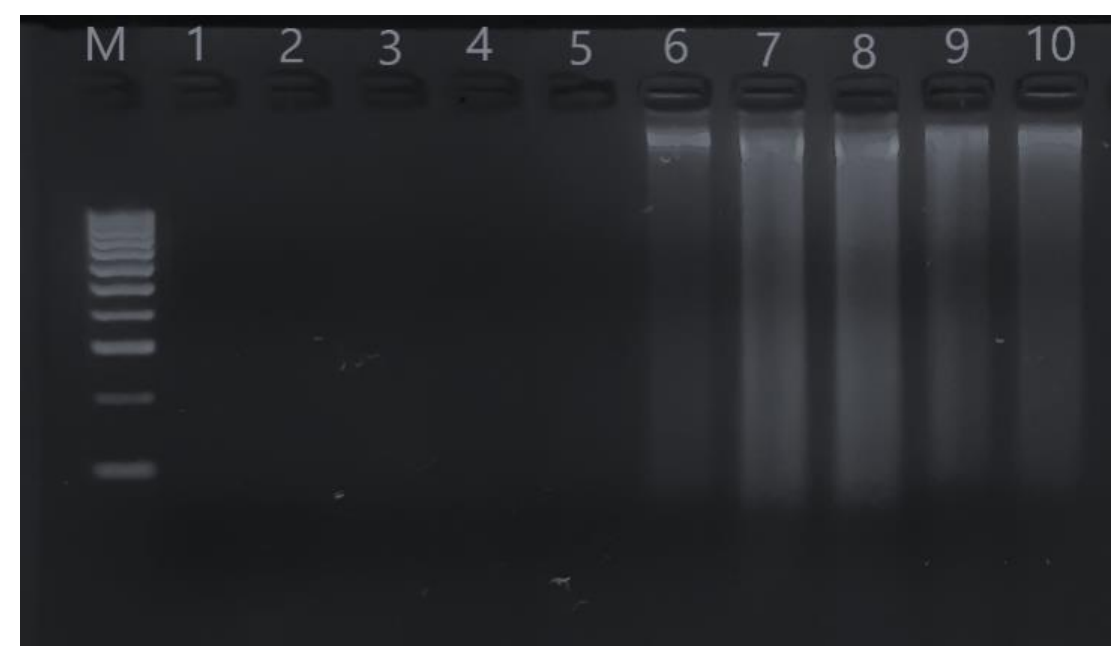

Figure 1: Electrophoresis results from total extracted DNA. M= $100 \mathrm{bp}$ DNA marker ladder, $1-10=$ samples of masked lovebird DNA. 
Electrophoresis results of DNA isolation visualized under $260 \mathrm{~nm}$ UV light with a $100 \mathrm{bp}$ DNA ladder marker produced a luminous DNA fragment due to the presence of SYBRSafe in each sample. DNA bands are seen in samples no 6, 7, 8, 9, and 10. Samples that are empty and do not display DNA bands show that the DNA in the sample does not exist or is so thin that it cannot be visualized. It should be optimized to improve the quality of extracted DNA by extending the incubation time, increasing the extracted feather sample, and increasing the concentration of proteinase $\mathrm{K}$ in the extraction solution. Harvey et al. (2006) stated that quantity of DNA that can be isolated from feather samples is not as high as the quantity of DNA which taken from blood samples, but by the consideration of time, convenience and minimal risk, feathers are selected as samples for molecular sex determine of the bird. The use of feathers as a sample for the sex determination of birds has the advantage that the process of sampling is easier and faster when compared to blood samples, otherwise, it can reduce stress on birds whose feather samples are taken (Khaerunnisa et al., 2013). The use of feathers can avoid pain in birds and reduce the risk of contamination and lower costs needed (Cerit and Avanus, 2007).

Amplification of the CHD gene of masked lovebird was performed by primers of NP, P2, and MP specific primers set. The visualization of PCR products was done by SYBRsafe DNA under UV light with a wavelength of $260 \mathrm{~nm}$. It showed that amplification of the CHD gene in male lovebird only generated a DNA fragment from the $\mathrm{Z}$ chromosome in size of $400 \mathrm{bp}$, whereas for female lovebird generated two DNA fragments of the $\mathrm{Z}$ chromosome in size of $400 \mathrm{bp}$ and $\mathrm{W}$ chromosome in size of $350 \mathrm{bp}$, due to length differences of the amplification products (Fridolfsson and Ellergen, 1999). PCR amplification in the CHD gene is used as a marker for sex determination because it will generate a PCR product that has a significant size difference between males and female birds (Morinha et al., 2012).

The results of PCR amplification of the CHD gene in masked lovebird by NP, P2, and MP primer pairs were presented in Figure 2. It showed that in sample no: 1, 4, 7, 8, and 9 was seen a single DNA band in size of $400 \mathrm{bp}$ to show that these five samples (50\%) were male masked lovebirds. Whereas in sample no: 2, 3, 5, 6, and 10 which generated two (double) DNA bands in the size of 350 bp and 400 $\mathrm{bp}$, it showed that these five samples (50\%) were female masked lovebirds. Based on the interpretation presented in Table 2, from the ten samples of tested masked lovebirds, there were five male lovebirds and five female lovebirds.

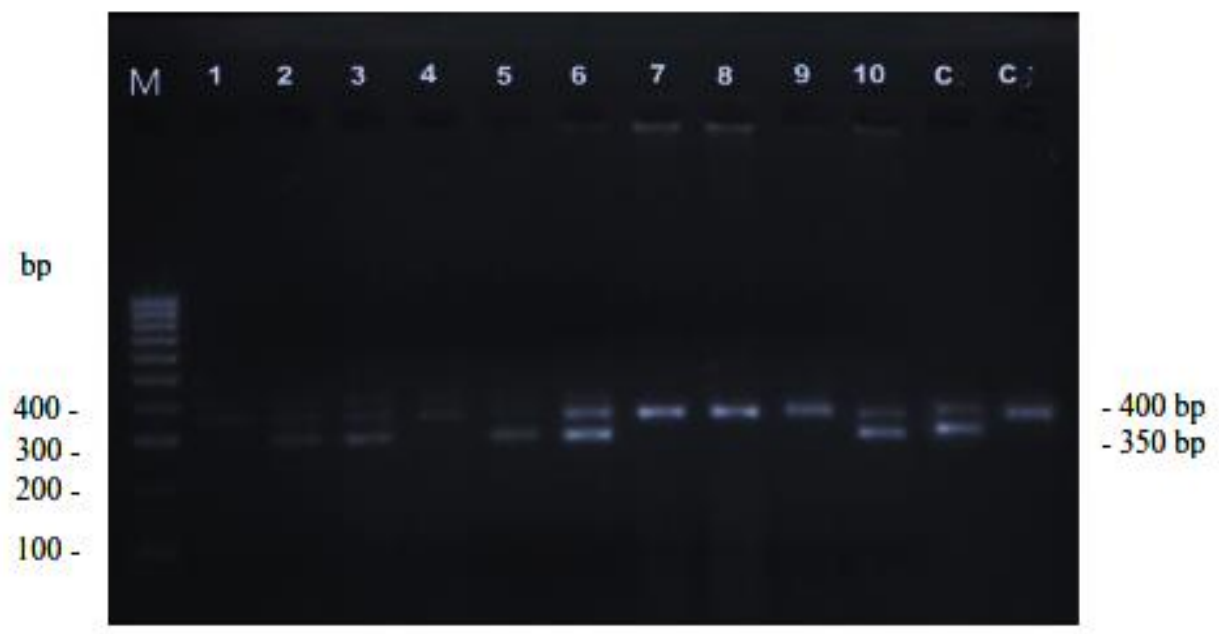

Figure 2: Electrophoresis the PCR product of the CHD gene from masked lovebirds. $\mathrm{M}=$ marker (hyperladder $100 \mathrm{bp}$ ), $1-10=$ lovebird samples, $\mathrm{C} Q=$ female control, $\mathrm{C} \hat{\delta}=$ male control.

This molecular sex determination study on masked lovebird (Agapornis personata) were in line with the results of the sex determination study on other lovebird species, namely peach-faced lovebird (Agapornis roseicollis) conducted by Nugraheni et al. (2019) which states that the CHD gene 
amplification in peach-faced lovebird can be well done by PCR techniques used NP, P2, MP primers set. Meanwhile, other researchers reported the same study results, namely that the use of NP, M and MP primers to amplify the CHD gene can be well done for sex determination study on captive birds derived from sixteen diverse birds from eleven bird families (Purwaningrum et al., 2009)

\begin{tabular}{|c|c|c|c|c|}
\hline No. & Sample Code & Electrophoresis result & Interpretation & Symbol \\
\hline 1. & AP-1 & One band & Male & ot \\
\hline 2. & AP-2 & Two bands & Female & 우 \\
\hline 3. & AP-3 & Two bands & Female & q \\
\hline 4. & AP-4 & One band & Male & 0 \\
\hline 5. & AP-5 & Two bands & Female & q \\
\hline 6. & AP-6 & Two bands & Female & q \\
\hline 7. & AP-7 & One band & Male & $\hat{0}$ \\
\hline 8. & AP-8 & One band & Male & $0^{\pi}$ \\
\hline 9. & AP-9 & One band & Male & $\hat{0}$ \\
\hline 10. & AP-10 & Two bands & Female & q \\
\hline
\end{tabular}

Table 2: Sex determination of masked lovebird based on the PCR products

The conclusions of this study were amplification by PCR technique using NP, P2, and MP primers set targeted for CHD gene in $\mathrm{Z}$ and $\mathrm{W}$ sex chromosome of masked lovebird (Agapornis personata) could be well performed. From total ten tested samples of masked lovebird, five samples $(50 \%)$ were male lovebirds and five samples $(50 \%)$ were female masked lovebirds

\section{Acknowledgment}

We would like to thank the Head of Biochemistry Departement, Faculty of Veterinary Medicine, Universitas Gadjah Mada, Yogyakarta for using the laboratory facilities to conduct this work. This research was supported by the research grant of Recognisi Tugas Akhir (RTA) from Universitas Gadjah Mada Yogyakarta, the fiscal year 2019 with Grant No. 3116/UN1/DITLIT/DIT-LIT/LT/2019 on April $11^{\text {th }}, 2019$.

\section{References}

Benjamin S and Yasyifa N. (2017). Teknik rahasia menciptakan variasi warna lovebird: dijamin pasti berhasil anti gagal. In Bahasa. Jakarta: Lembar Langit Indonesia. 6-16.

Cerit H and Avanus K. (2007). Sex determination by CHD-W and CHD-Z genes of avian sex chromosomes in Nymphicus hollandicus. Turk. J. Vet. Anim. Sci. 31: 371-374.

Fridolfsson A and Ellergen H. (1999). A simple and universal method for molecular sexing of nonratite birds. J. Avian. Biol., 30: 116-121.

Grant A. (2001). DNA sexing of brown kiwi (Apetryx mantelii) from feather samples. DOC Science Internal Series. Wellington: Department of Conservation. 5-15.

Dubiec A and Neubauer MZ. (2006). Molecular techniques for sex identification in birds. Biological Letters. 43(1): 3-12.

Handono B, Turut R, and Gunarso S. (2013). Lovebird: Sukses menangkarkan dan memelihara. In Bahasa. Jakarta: Penebar Swadaya.

Harvey M, Bonter D, Stenzler L, and Lovette I. (2006). Comparison of plucked feathers versus blood samples as DNA sources for molecular sexing. Journal of Field Orthinology. 77(2): 136-140. 
Hickman C, Roberts L, and Hickman F. (1984). Integrated principles of zoology. Seventh Ed. Toronto: Mosby College Publishing.

Ito HA, Abe M, Murase T, and Tsubota T. (2003). Sex identification by alternative polymerase chain reaction methods in Falconiformes. Zoological Science 20: 339-344.

Khaerunnisa I, Sari E, Ulfah M, Jakaria, and Sumantri C. (2013). Avian sex determination based on chromodomaine helicase DNA-binding (CHD) genes using polymerase chain reaction (PCR). Media Peternakan. 36(2): 8590.

Morinha F, Cabral J, and Bastos E. (2012). Molecular sexing of birds: A comparative review of polymerase chain reaction (PCR)-based methods. Theriogenology. 78: 703-714.

Nugraheni P, Purwaningrum M, Widayanti R, and Haryanto A. (2019). Sex determination of peachfaced lovebird (Agapornis roseicollis) using polymerase chain reaction (PCR) techniques. IOP Conf, Series: Earth and Environmental Science 355. 012111.

Nugroho H and Zein MS. (2015). Evaluasi metode penentuan jenis kelamin pada nuri kepala hitam (Lorius Iory, Linnaeus 1758). In Bahasa. Zoo Indonesia 2015. 24(2): 83-93.

Nurfianto TA and Mulyanto E. (2017). Pengenalan jenis burung lovebird dengan menggunakan content-based image retrival berbasis color histogram. In Bahasa. Skripsi: Universitas Dian Nuswantoro.

Purwaningrum M, Nugroho HA, Asvan A, Karyanti K, Alviyanto B, Kusuma R, and Haryanto A. (2019). Molecular techniques for sex identification of captive birds. Veterinary World, 12(9): 15061513.

Yudiantoro and Maloedyn S. (2011). Lovebird si cantik bersuara merdu. In Bahasa. Jakarta: AgroMedia Pustaka. 